EGU2020-16794, updated on 18 Jun 2021

https://doi.org/10.5194/egusphere-egu2020-16794

EGU General Assembly 2020

(c) Author(s) 2021. This work is distributed under

the Creative Commons Attribution 4.0 License.

\title{
Geochemistry of basic magmatism of Western Antarctic Rift: implications for volatiles storage and recycling in the mantle
}

\author{
Pier Paolo Giacomoni ${ }^{1}$, Carmelo Ferlito ${ }^{2}$, Costanza Bonadiman ${ }^{1}$, Federico Casetta ${ }^{1}$, Luisa Ottolini ${ }^{3}$, \\ Alberto Zanetti ${ }^{3}$, and Massimo Coltorti ${ }^{1}$ \\ ${ }^{1}$ Department of Physics and Earth Science, University of Ferrara, Ferrara, Italy (gcmppl@unife.it) \\ ${ }^{2}$ Department of Biological, Environmental and Geological Sciences, University of Catania, Catania, Italy \\ ${ }^{3}$ Institute of Geoscience and Georesources-CNR, Pavia (Italy)
}

The petrologic study of olivine-hosted melt inclusions (MIs) from alkaline primary Cenozoic basalts of Northern Victoria Land (Antarctica) provide new insights on the role of volatiles in the onset of rift-related magmatism. The concentration of volatile species $\left(\mathrm{H}_{2} \mathrm{O}, \mathrm{CO}_{2}, \mathrm{~F}, \mathrm{Cl}\right)$ have been determined by Secondary Ion Mass Spectrometry (SIMS) on a selection of MIs which have been previously re-homogenized at high pressure and temperature conditions in order to avoid any heterogeneity and reducing the $\mathrm{H}$ diffusion. The least differentiated MIs vary in composition from basanitic to alkaline basalts, analogously to what is found in McMurdo volcanics, while their volatile concentrations reach up to $2.64 \mathrm{wt} \% \mathrm{H}_{2} \mathrm{O}, 3900 \mathrm{ppm} \mathrm{CO} \mathrm{CO}_{2}, 1377 \mathrm{ppm} \mathrm{F}$ and $1336 \mathrm{Cl}$. Taking into account the most undegassed $\mathrm{Mls}$ a $\mathrm{H}_{2} \mathrm{O} /\left(\mathrm{H}_{2} \mathrm{O}+\mathrm{CO}_{2}\right)$ ratio equal to 0.88 was determined, which in turn brings the $\mathrm{CO}_{2}$ content in the basanitic melt with the highest water content up to $8800 \mathrm{ppm}$.

Major and trace element melting modelling indicate that basanite and alkali basalt composition can be reproduced by 3 and $7 \%$ of partial melting of an amphibole-bearing spinel lherzolite respectively. Assuming a perfect incompatible behavior for $\mathrm{H}_{2} \mathrm{O}$ and $\mathrm{CO}_{2}$ these melting proportions allow to constrain the water and $\mathrm{CO}_{2}$ contents in the mantle source in the range 780-840 and 264-273 ppm respectively. The resulting $\mathrm{CO}_{2} / \mathrm{Nb}, \mathrm{CO}_{2} / \mathrm{Ba}$ and $\mathrm{H}_{2} \mathrm{O} / \mathrm{Ce}$ ratio are lower than those estimated for Depleted MORB Mantle (DMM), suggesting that the NVL Cenozoic alkaline magmatism could be originated by an enriched mantle source composed by a range from $70 \%$ to $60 \%$ of Enriched Mantle (EM) and from 30\% to $40 \%$ of Depleted Morb Mantle (DMM).

A global comparison of fluid-related, highly incompatible and immobile/low incompatible elements such as $\mathrm{Li}, \mathrm{K}, \mathrm{Cl}, \mathrm{Ba}, \mathrm{Nb}$, Dy and $\mathrm{Yb}$ allow to put forward that the prolonged ( 500 to $100 \mathrm{Ma}$ ) Ross subduction event played a fundamental role in providing the volatile budget into the lithospheric mantle before the onset of the Cenozoic continental rifting. 